\title{
Using Inhibitors for Preventions of Corrosion "Cancer" of Reinforced Concrete Constructions
}

\author{
Albana Jano ${ }^{1}$, Valbona Hoxha ${ }^{1}$, Alketa Lame ${ }^{2}$ and Efrosini Kokalari ${ }^{2}$ \\ ${ }^{1}$ Polytrchnic University of Tirana, \\ Address, City, Country \\ Albana.Jano@fishn.edu.al \\ ${ }^{2}$ University of Tirana
}

\begin{abstract}
Corrosion undermines the physical integrity of structures and can lead to destruction of property and loss of life. Chlorideinduced steel corrosion is one of the major worldwide deterioration problems for steel reinforced concrete structures. The use of green inhibitors in producing high performance concrete has increased significantly. The aim of our study was to investigate the efficiency of green inhibitor and migration inhibitor admixed in concrete. The concrete samples were exposed in aggressive media $\mathrm{H}_{2} \mathrm{SO}_{4} 1 \mathrm{M}$ and $10^{-3} \mathrm{Cl}^{-}$. As corrosion inhibitor we have used locust bean gum as a green inhibitor and methionine+butanolamine as migration inhibitor. Half-cell potential, polarization resistance and Tafel extrapolation methods are used for inhibitor efficiency testing. The results shows high resistance polarization and low corrosion rate for concrete sample with inhibitor. The corrosion rate decrease approximately $90 \%$ in presence of locust bean gum and $80 \%$ in presence of migration inhibitor
\end{abstract}

Keywords: Green inhibitor, Migration inhibitor, locust bean gum

\section{Introduction}

The corrosion of steel reinforcement is one of the main causes of premature deterioration of reinforced concrete. Rapid deterioration can be caused by chloride ions in a marine zone or due to the use of thaw salts [1] or by carbonation in urban zones [2]. The use of inhibitors of low environmental impact is becoming more popular due to the major concerns about the use of these chemicals. Locust bean gum is an organic compound extracted by endosperms of carob tree. It is cheap and friendly with environment. Migrating corrosion inhibitors are able to penetrate into existing concrete to protect steel from chloride attack. The inhibitor migrates through the concrete capillary structure, first by liquid diffusion via the moisture that is normally present in concrete, then by its high vapor pressure and finally by following hairlines and micro cracks. The diffusion process requires time to reach the rebar surface and to form a protective layer (3).

\section{Paper Format}

The objective of this investigation has been the study of corrosion protection efficiency of locust bean gum as a green inhibitor and methionine+amino-2-butanol-1 as migration inhibitor added in concrete.

Three concrete samples one blank sample without inhibitor, one with $1 \mathrm{~g} / \mathrm{L}$ locust bean gum and one with methionine $1 \mathrm{~g} / \mathrm{l}+$ amino-2-butanol-1 8g/L with dimensions $10 \times 10 \times 20 \mathrm{~cm}$ were prepared using a $20 \mathrm{~cm}$ steel rebar and one $20 \mathrm{~cm}$ Inconel for the counter electrode. A concrete mixture containing commercial sand, Titan cement, concrete mixture ratio: water/cement $=0.53$ and inert/cement $=2.25$. The inhibitor was added in the concrete. Concrete were cured for 28 days. After curing, the concrete samples were immersed in acid sulfuric $(1 \mathrm{M})$ in presence of $10^{-3} \mathrm{M} \mathrm{Cl}^{-}$at ambient temperatures and are testing for 122 day. Clear silicon was applied to the concrete/metal interface to prevent easy access for ions.

The corrosion behavior of steel rebar was monitored by electrochemical experiments included the following techniques: linear polarization resistance, potentiodynamic test and open-circuit potential measurements. All tests were conducted in three-compartment electrochemical cells, where i) the working electrode was the steel sample; ii) the counter electrode was inconel; and iii) the reference electrode was a $\mathrm{Hg} / \mathrm{Hg}_{2} \mathrm{SO}_{4}$.

Effectiveness inhibitors were based on changes in the polarization resistance, corrosion rate and the corrosion potential of the rebar, measurements that can be performed without destruction to the reinforcing steel. This data can 
provide early warning of structural distress and evaluate the effectiveness of corrosion control strategies that have been implemented. The key to fighting corrosion is to introduce preventative measures.

Changes in the resistance polarization ( $\mathrm{Rp}$ ) were monitored weekly, the corrosion potential of the rebar was monitored daily and the potentialdynamic polarization was done at the last day using Potentiostat/Galvanostat PJT-24. Potential values were recorded and plotted with respect to time.

\section{Results}

\subsection{Corrosion Potential}

The corrosion inhibition for locust bean gum and migration inhibitor has been investigated over e period of 122 days. According to the ASTM (John.P.Broomfield. 2007, C876-09, 2009) standard, if the open circuit potential (corrosion potential) is $-0.564 \mathrm{mV}$ or higher, this indicates a $90 \%$ probability that no reinforcing steel has corroded. Corrosion potentials more negative than $-0.564 \mathrm{mV}$ are assumed to have a greater than $90 \%$ likelihood of corrosion.

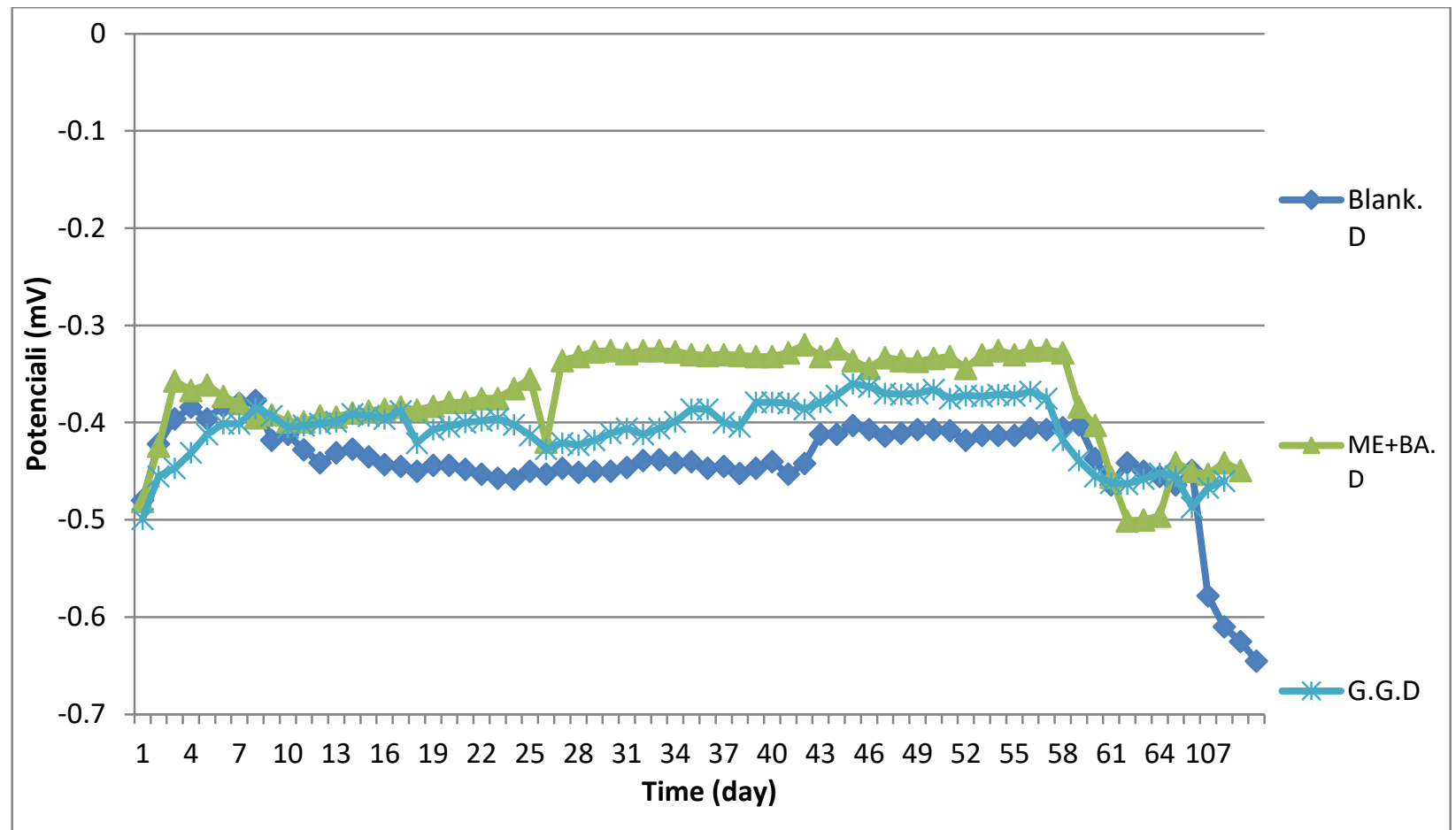

Fig. 1: Comparison of corrosion potential vs time for sample with locust bean gum, sample with migration inhibitor (methionine+butanolamina) and untreated sample (blank).

\subsection{Polarization Resistance}

The method is based on the observation of the linearity of the polarization curves near the potential $\mathrm{E}_{\text {corr. }} \mathrm{Rp}$ value is related to the corrosion current $I_{\text {corr }}$ by means of the expression: $I_{k o r r}=B / R p \quad R p=\Delta E / \Delta I \quad$ icorr $=$ Icorr $/ A$

The potential of the reinforcement was scanned $20 \mathrm{mV}$ from the open-circuit potential (OCP) of the sample, at a scan rate of $6 \times 10^{-3} \mathrm{mV} / \mathrm{s}$. Inhibitor treated concrete samples have higher Rp values compared with the blank sample. Figure shows a declining trend stable polarization resistance values after 122 days of testing for the treated concrete. Polarization resistance measurements show a reduced corrosion rate for the samples with inhibitor, while the blank sample has an increasing corrosion rate. Both of samples, with locust bean gum and methionine+butanolamine showed an average corrosion rate of $0.34 \mu \mathrm{A} / \mathrm{cm}^{2}$ (with a decreasing trend) 
compared to the blank samples showing a rate of $2.04 \mu \mathrm{A} / \mathrm{cm}^{2}$. The rebar treated with methionine+butanolamine has the highest polarization resistance. The results showed the possibility of migration of the migration inhibitor and the ability to create e thin protect layer. The samples treated with inhibitor have the ability to passivity the steel bar even in the presence of chloride ions $(3,4)$. The values of corrosion rate in $\mu \mathrm{A} / \mathrm{cm}^{2}$ for treated and untreated are shown in table.

Table 1: Values of Rp and Icorr for concrete samples immersed in $\mathrm{H}_{2} \mathrm{SO}_{4} 1 \mathrm{M}$ and $10^{-3} \mathrm{Cl}$ - solution, day 122.

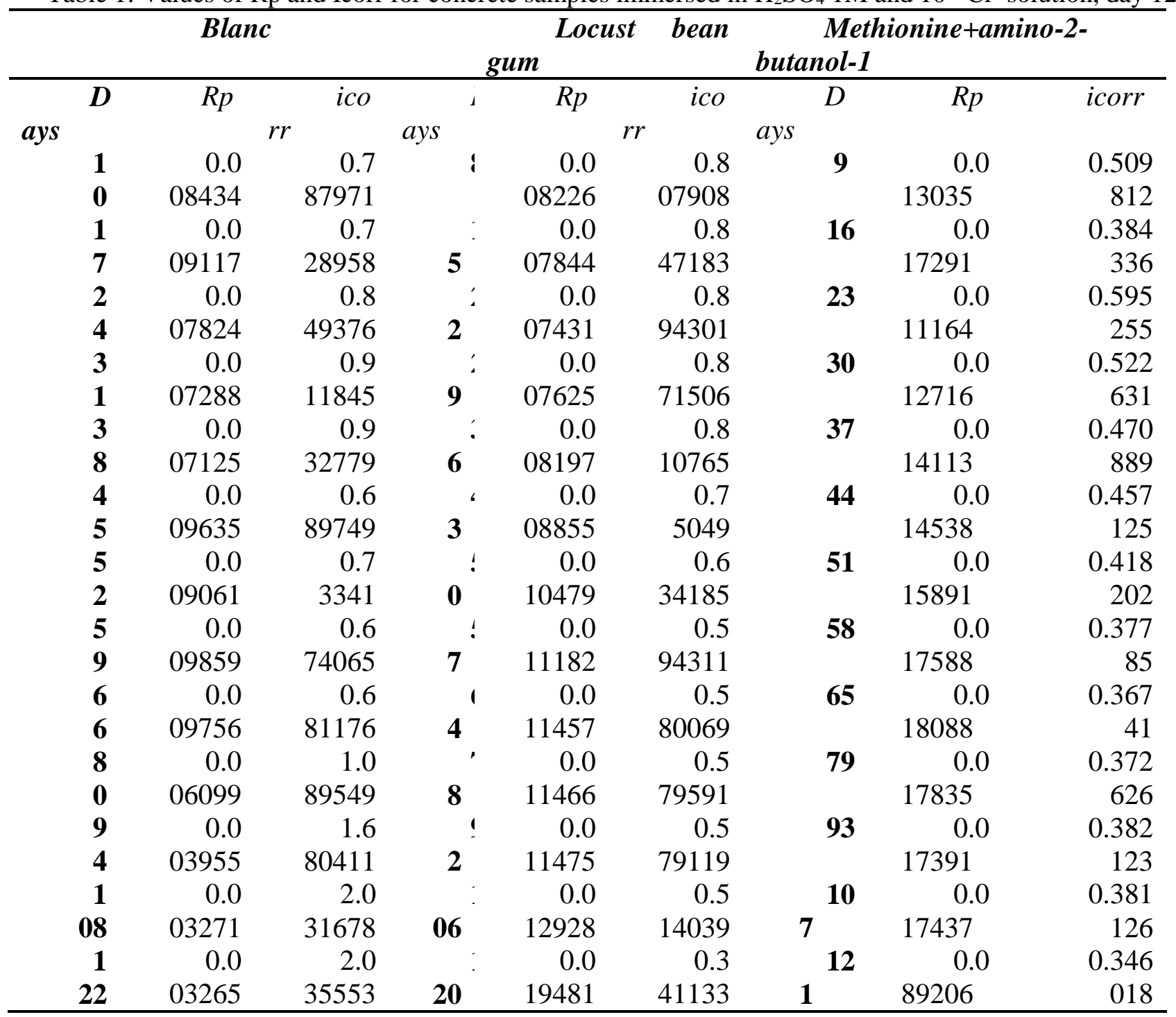




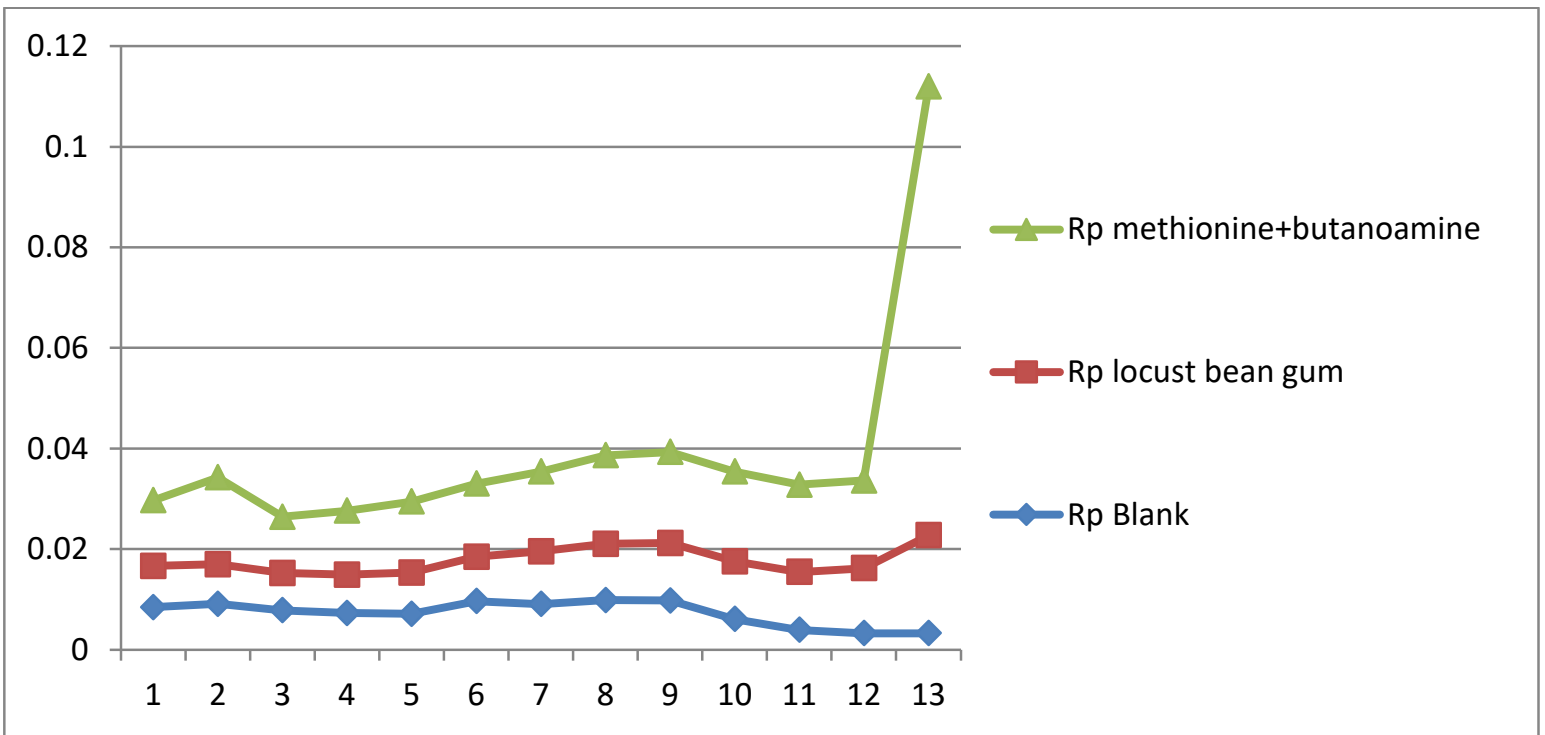

Fig. 2: Comparison of polarization resistance (RP) for locust bean gum, methinine+amino-2-butanol-1 \& blank concrete samples.

\subsection{Electrochemical Polarization}

The figure shows the comparison of the polarization behavior from a potentidynamic tests of steel rebar in acid sulfuric $1 \mathrm{M}$, in presence of chloride ions $10^{-3} \mathrm{M}$ solutions. Corrosion potential gets more positive values and the corrosion rate mitigates in presence of inhibitors. The rebar steel treated with guar gum has a corrosion rate $0.0000241 \mathrm{~mm} / \mathrm{year}$; the rebar steel treated with migration inhibitor has a corrosion rate $0.000398 \mathrm{~mm} / \mathrm{year}$ and the untreated steel bar (blank sample) has a corrosion rate $0.0021 \mathrm{~mm} /$ year.

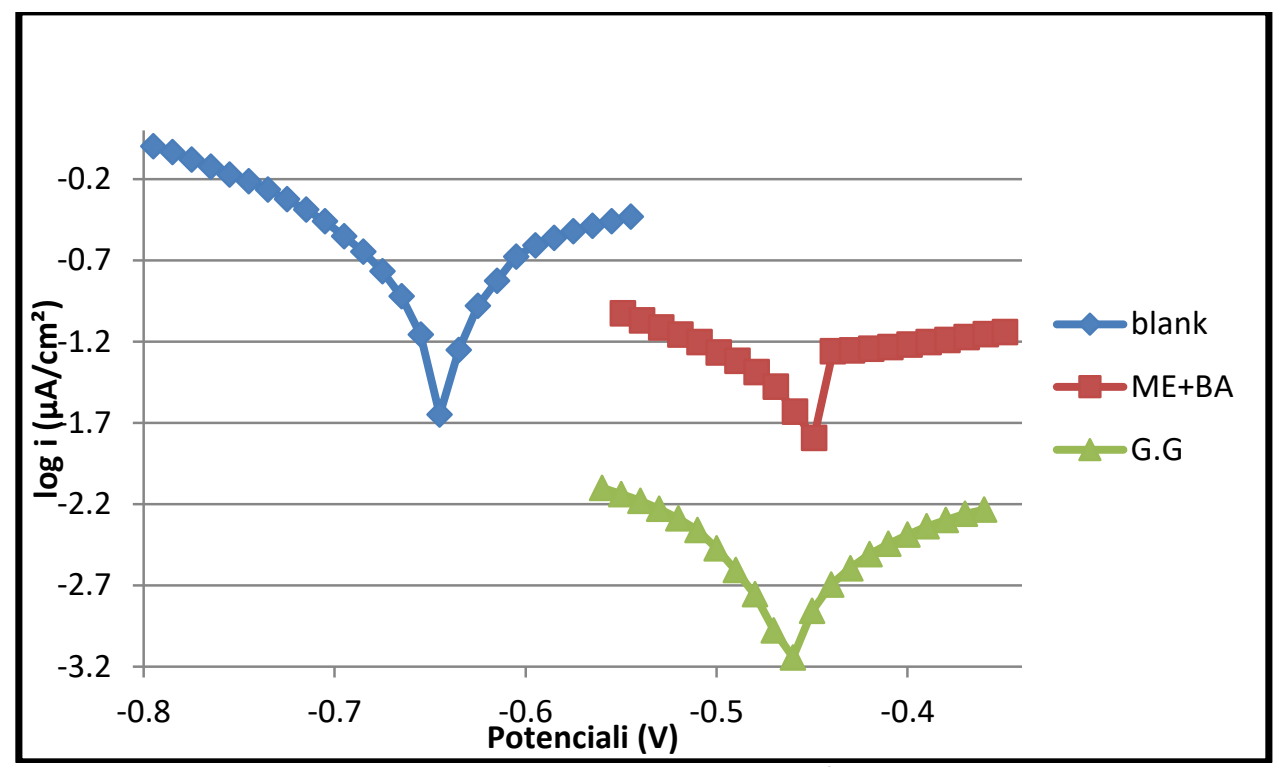

Fig. 3: Polarization curves of steel bar in $\mathrm{H}_{2} \mathrm{SO}_{4} 1 \mathrm{M}$ and $10^{-3} \mathrm{M} \mathrm{Cl}^{-}$, with and without inhibitor. 
Table 2: Rate corrosion for steel in concrete and steel in acid $(5,6,7)$.

\begin{tabular}{|c|c|c|c|c|}
\hline & \multicolumn{2}{|c|}{ Steel in concrete } & \multicolumn{2}{|c|}{ Steel in $\mathrm{H}_{2} \mathrm{SO}_{4}$} \\
\hline & icor & $V_{\text {corr }}$ & $\overline{\text { icor }}$ & $V_{\text {corr }}$ \\
\hline & $\mathbf{r}$ & (mm/year) & $\mathbf{r}$ & $(\mathrm{mm} / \mathrm{year})$ \\
\hline \multirow{2}{*}{ Blanc } & 0.1 & 0.0021 & 53 & 6.267 \\
\hline & 76 & & 7.96 & \\
\hline \multirow[t]{2}{*}{ Locust bean gum } & 0.0 & $2.41 \mathrm{E}-05$ & 51 & 0.59 \\
\hline & 021 & & .31 & \\
\hline Methionine+butano & 0.0 & 0.000398 & 33 & 0.39 \\
\hline lamine & 34162 & & .09 & \\
\hline
\end{tabular}

\section{Conclusion}

Guar gum and migration inhibitors added in concrete demonstrated corrosion inhibition of rebar and can improve the life of reinforced concrete structures. Rp increase from 0.008226 to 0.019481 for the sample treated with locust bean gum and $\mathrm{Rp}$ increase from 0.013035 to 0.089206 for the sample treated with migration inhibitor methionine+butanolamine. The samples treated with locust bean gum and methionine+butanolamine showed an average corrosion rate of $0.34 \mu \mathrm{A} / \mathrm{cm}^{2}$ compared to the blank samples showing a rate of $2.04 \mu \mathrm{A} / \mathrm{cm}^{2}$. Potentiodynamic polarization method showed that the sample treated with guar gum has a corrosion rate $0.0000241 \mathrm{~mm} /$ year; the sample treated with migration inhibitor has a corrosion rate $0.000398 \mathrm{~mm} /$ year and the blank sample has a corrosion rate $0.0021 \mathrm{~mm} /$ year. This reduction in the corrosion rate will increase life expectancy by more than 50-60 years (3). Neutralizing effects of the inhibitor assured satisfactory corrosion resistance even in the presence of $10^{-3} \mathrm{M}$ chloride ions.

\section{References}

[1] Lee HS, Ryu HS, Park WJ and Ismail MA Comparative study on corrosion protection of reinforcing steel by using amino alcohol and lithium nitrite inhibitors Materials (Basel) 2015;8:251-269. DOI: 10.3390/ma8010251

[2] E Redaelli and L Bertolini, Electrochemical repair techniques in carbonated concrete, Part I: Electrochemical realkalisation Journal of Applied Electrochemistry. 2011;41:817-827. DOI: 10.1007/s10800-011-0301-4

[3] B Bavarian, A Oluwaseye and L Reiner, Migrating Corrosion Inhibitors to Protect Reinforced Concrete Structures, College of Engineering and Computer Science California State University, Northridge, USA 91330 Jessica Meyer Cortec Corporation 4119 White Bear Parkway St. Paul, MN, USA 55110

[4] A Abdulrahman and I Mohammad, Eco-friendly green inhibitor to improve the strength of concrete contaminated by chloride and sulphate, Faculty of Civil Engineering, Universiti Teknologi Malaysia, 81310 UTM, Johor Bahru, Johor, Malaysia

[5] A Jano, A Lame (Galo) and E Kokalari (Teli), Use of extracted green inhibitors as a friendly choice in corrosion protection of low alloy carbon steel, KUI (Kemija u Industriji) 11-12/2012, Number 13/2012, open access: http://www.hdki.hr/kui/en/index.htlm http://hrcak.srce.hr/kui.

[6] A Lame,A Jano and E Teli, Sulfuric acid corrosion protection efficiency of locust bean gum for different steels used as concrete armor, Proceedings ISBN 978-9928-4011-9-9, International Conference of Ecosystems (ICE)-2012, p.449-455 
[7] A Lame, E Teli and A Jano, Use of green inhibitors for concrete armor protection against $\mathrm{H} 2 \mathrm{SO} 4$ corrosion, Asian Journal of Chemistry Vol.25, No.7, (2013), ISSN: 0975-7077, p.4017-4021. 